\title{
Evaluation of the Relationship Between Ocular Surface Disease Index and Dry Eye Test Parameters in Computer Users
}

\author{
Bilgisayar Kullanıcılarında Oküler Yüzey Hastalığı Indeksi ve Kuru Göz Testi Parametreleri \\ Arasındaki Ilișkinin Değerlendirilmesi
}

\author{
Lokman Balyen \\ Department of Ophthalmology, Faculty of Medicine, Kafkas University, Kars, Turkey
}

\begin{abstract}
Aim: The present study aims to evaluate the relationship between ocular surface disease index (OSDI) and dry eye test parameters in computer users.

Material and Method: In this current study, 62 individuals between the ages of 20 and 40 years and who spent at least 6 hours of their daily life in front of a computer were included. In addition to the complete ophthalmologic examination, dry eye tests including Schirmer I test, Schirmer II test, tear breakup time (TBUT), ocular surface fluorescein and lissamine green staining were performed on each volunteer for both eyes after completion of the OSDI questionnaire.
\end{abstract}

Results: Of 62 participants, 42 (67.7\%) were female and 20 (32.3\%) were male. The mean age of participants was $30.06 \pm 4.794$ (21-39) years. The mean computer use time of the participants was $10.15 \pm 3.040(6-16)$ hours/day. The mean OSDI score was $31.0742 \pm 15.05892$ (8.3-75). There was a significant negative correlation between OSDI score and TBUT in the right eye ( $r=-0.718$, $p=0.000)$ and the left eye $(r=-0.667, p=0.000)$. However, there was a slightly negative correlation between OSDI score and Schirmer $I-I I$ tests in the right eye $(r=-0.273, p=0.032 ; r=-0.295, p=$ 0.020 , respectively) and the left eye $(r=-0.308, p=0.015 ; r=$ $-0.296, p=0.019$, respectively). There was a significant difference between OSDI score and ocular surface staining scores in both eyes $(p=0.000)$. There was a significant positive correlation between OSDI score and computer use time ( $r=0.642, p=0.000)$. However, there was no correlation between age, gender, smoking, wearing glasses and OSDI score ( $p>0.05$ ).

Conclusion: Long-term computer use and longer duration of occupation may lead to ocular surface problems. The OSDI was found to be strongly associated with daily computer use time, TBUT, and ocular surface staining scores in computer users.

Key words: computer; dry eye; ocular surface disease index; ocular surface staining; Schirmer test; tear breakup time test

\section{ÖZET}

Amaç: Bu çalıșmada bilgisayar kullanıcılarında oküler yüzey hastaı̆ğı indeksi (OYHi) ve kuru göz testi parametreleri arasındaki ilișkiyi değerlendirmeyi amaçlamaktadır.

Materyal ve Metot: Bu prospektif çalıșmada, 20-40 yașları arasında ve günlük yașamlarının en az 6 saatini bir bilgisayar bașında geçiren 62 kiși dâhil edildi. Tüm oftalmolojik muayenenin yanı sıra, her gönüllüde OYHI anketinin tamamlanmasından sonra her iki göz için Schirmer I test, Schirmer II test, gözyașı kırılma zamanı (GKZ), oküler yüzey fluoresein ve lissamin yeșili boyama dâhil kuru göz testleri yapıldı.

Bulgular: Çalıșmaya dâhil edilen 62 katılımcının 42'si (\% 67,7) kadın, 20'si (\% 32,3) erkekti. Katılımcıların yaș ortalaması 30.06 \pm 4.794 (21-39) yıl idi. Katılımcıların bilgisayar kullanım süresi ortalama $10.15 \pm 3.040$ (6-16) saat/gün idi. Ortalama OYHi skoru $31.0742 \pm 15.05892$ (8.3-75) idi. OYHi skoru ile sağ göz $(r=$ $-0.718, p=0.000)$ ve sol göz $(r=-0.667, p=0.000) G K Z$ arasında anlamlı bir negatif korelasyon vardı. Ancak OYHi skoru ile sağ göz (sırasıly $r=-0.273, p=0.032 ; r=-0.295, p=0.020$ ) ve sol göz (sırasıly $r=-0.308$ ), $p=0.015 ; r=-0.296, p=0.019$ ) Schirmer I-Il testleri arasında hafif bir negatif korelasyon vardı. Her iki gözde OYHi skoru ile oküler yüzey boyama skorları arasında anlamı bir fark vardı $(p=0.000)$. OYHi skoru ile bilgisayar kullanım süresi arasında anlamlı bir ilișki bulundu ( $r=0.642, p=0.000)$. Ancak yaș, cinsiyet, sigara, gözlük kullanımı ile OYHi skoru arasında korelasyon yoktu ( $p>0.05)$.

Sonuç: Uzun süreli bilgisayar kullanımı ve daha uzun çalıșma süresi oküler yüzey sorunlarına neden olabilir. Bilgisayar kullanıcılarında OYHi'nin günlük bilgisayar kullanım süresi, GKZ ve oküler yüzey boyama skorları ile güçlü bir șekilde ilișkili olduğu bulundu.

Anahtar kelimeler: bilgisayar; kuru göz; oküler yüzey hastalık indeksi; oküler yüzey boyama; Schirmer testi; gözyașı kırılma zamanı

Iletișim/Contact: Lokman Balyen, KAÜ Tip Fakültesi, Göz Hastalıkları Anabilim Dal, Kars • Tel: 05058747473 • E-mail: lbalyen@hotmail.com • Geliș/Received: 14.10.2019 • Kabul/Accepted: 17.12.2019

ORCID: Lokman Balyen, 0000-0003-4298-7256 


\section{Introduction}

The viewing of digital electronic screens in the workplace, at home or as portable equipment is universal. Nowadays, in addition to desktop, laptops, and tablet computers, electronic books, smartphones, and other electronic devices have become substantially widespread in daily life worldwide. Computers are used for both professional and social purposes in daily life. Given the enormous growth rates of digital device use in recent years, millions of people of all ages are at risk of dry eye disease (DED) ${ }^{1-4}$. However, there are many risk factors associated with increased risk of the DED, including older age, female sex, environmental conditions, occupational factors, nutritional factors, hormonal status, systemic medications, topical ophthalmic medications, contact lens wear, refractive surgery, Parkinson's disease, diabetes mellitus, autoimmune disease, hepatitis $\mathrm{C}$, human immunodeficiency virus infection, radiation therapy, and bone marrow transplantation ${ }^{5}$. The lacrimal functional unit includes the ocular surface, lacrimal glands, meibomian glands, and associated sensory and motor nerves and eyelids. The tear film consists of 3 layers; mucous, aqueous, and lip$\mathrm{id}^{5}$. The DED, especially affecting middle-aged or older individuals, is one of the most common ocular surface diseases on a global scale in recent years ${ }^{6-8}$. The DED has been a major public health problem in older people for years, especially prolonged use of electronic devices in modern society has posed a challenge for DED in recent years ${ }^{9,10}$. The DED, a multifactorial disorder of tear film and ocular surface, results in increased osmolarity and instability of the tear film, the discomfort of eye, visual impairment and potential damage and inflammation of the ocular surface ${ }^{6-8,11}$. Visual disturbances such as blurred, foggy or fluctuating vision and glare are very common in people with DED. The DED also affects the quality of life of the individuals, including social, physical, psychological and workplace productivity $^{7,12}$. The DED is normally caused by inadequate tear production, excessive tear evaporation and insufficiency of the production of other components of tears (lipids and mucous) ${ }^{13}$.

In the United States, about one-quarter of the population suffers from DED or instability of ocular surface ${ }^{14}$. It is estimated that the prevalence of this condition is higher in Turkey. Computer vision syndrome (CVS) is a group of eye and vision problems related to excessive computer use. The CVS is very frequent in the world and approximately 60 million people worldwide suffer from it and one million new individuals are added each year. In studies on CVS have suggested that CVSrelated symptoms may be common among long-term computer users and that the prevalence of CVS ranges from $75 \%$ to $90 \%$. It is not only resulting in visual discomfort but also resulting in low quality of life and low productivity in the workplace $e^{1-3,15,16}$. Dry eye is a substantial contributor to $\mathrm{CVS}^{2}$. There are many symptoms of CVS, including dry eye, red eye, eye strain, irritation, burning, foreign body sensation, watering, blurred vision, diplopia, cephalgia, photophobia, difficulty in focusing and changes in color perception ${ }^{3}$. The purpose of the present study was to evaluate the prevalence of dry eye problems in long-term computer users and to investigate the relationship between long-term computer use and ocular surface disease index and dry eye test parameters.

\section{Materials and Methods}

Nature and possible complications of the study were explained clearly to each participant before the commencement of the study and then informed consent was obtained from each participant. Sixty-two volunteer participants from various departments of the university, whose computer use time was at least 6 hours, aged between 20-40 and willing to give consent for the study, were included in this study. This investigation adhered to the tenets of the World Medical Association Declaration of Helsinki. The experimental protocol and consent procedures were approved by the Institutional Review Board of the University of Kafkas Faculty of Medicine Ethics Committee (approval no. 13.12.2017/02). A cross-sectional study was conducted to determine the dry eye prevalence in individuals working in front of a computer for a long time at various departments of our university. Detailed medical history of the participants was questioned and individuals who were $<20$ or $>40$ years of age, who were previously diagnosed with dry eye syndrome, who had an ocular surface disease, refractive surgery, extraocular or intraocular surgery, and ocular trauma were excluded. Additionally, patients with nasolacrimal obstruction, acute or chronic ocular infection, allergic conjunctivitis, and patients with eyelid abnormalities, systemic diseases such as diabetes and rheumatoid arthritis that may cause ocular surface changes, rheumatic or dermatological disease such as rosacea and Stevens-Johnson syndrome were excluded. In addition, patients who used contact lenses, who received topical lubricants, those who used topical or systemic corticosteroids and 
antihistamines, and those who received antihistamine, anticholinergic and similar systemic drugs known to cause dry eye were also excluded from this study.

The best-corrected visual acuity of all participants was evaluated with the Snellen chart. Intraocular pressures of the participants were measured by air-puff tonometer, and anterior segment structures were evaluated by slit-lamp biomicroscopic examination and fundus examinations were performed with fundoscopy. Individuals with characteristics that would adversely affect the results of the study were excluded. The demographic characteristics of the participants such as age, gender, smoking, wearing glasses, how many hours a day they stayed at the computer and the presence of ocular symptoms were recorded. Then, the ocular surface disease index (OSDI) questionnaire which consisted of 12 questions was administered to the participants (Table 1) ${ }^{17}$. The OSDI questionnaire consists of three main sections: ocular symptoms, vision-related functions, and environmental factors. The OSDI score was obtained by multiplying the sum of the scores given to 12 questions by 25 , as indicated in the original questionnaire, divided by the number of questions answered ${ }^{18}$. The OSDI questionnaire is a scoring system with a range of $0-100$. According to OSDI score; 0-12 points were considered as normal, 13-22 points as mild, 23-32 points as moderate and 33-100 points as severe ocular surface disease ${ }^{19}$.

Table 1. Ocular surface disease index

\begin{tabular}{|c|c|c|c|c|c|c|c|}
\hline \multicolumn{8}{|c|}{ Have you experienced any of the following during the last week? } \\
\hline \multirow[b]{2}{*}{1} & & $\begin{array}{l}\text { All of the } \\
\text { time }\end{array}$ & $\begin{array}{l}\text { Most of the } \\
\text { time }\end{array}$ & $\begin{array}{l}\text { Half of the } \\
\text { time }\end{array}$ & $\begin{array}{l}\text { Some of the } \\
\text { time }\end{array}$ & $\begin{array}{l}\text { None of the } \\
\text { time }\end{array}$ & \\
\hline & \multicolumn{7}{|l|}{ Eyes that are sensitive to light? } \\
\hline \multicolumn{8}{|c|}{ Eyes that feel gritty? } \\
\hline \multicolumn{8}{|c|}{ Painful or sore eyes? } \\
\hline \multirow{2}{*}{\multicolumn{8}{|c|}{$\begin{array}{l}\text { Blurred vision? } \\
\text { Poor vision? }\end{array}$}} \\
\hline \multirow[t]{2}{*}{5} & & & & & & & \\
\hline & & (4) & (3) & (2) & (1) & $(0)$ & \\
\hline \multicolumn{8}{|c|}{ Subtotal score for answers 1 to $5:(A)$} \\
\hline \multicolumn{8}{|c|}{ Have problems with your eyes limited you in performing any of the following during the last week? } \\
\hline & & $\begin{array}{l}\text { All of the } \\
\text { time }\end{array}$ & $\begin{array}{l}\text { Most of the } \\
\text { time }\end{array}$ & $\begin{array}{l}\text { Half of the } \\
\text { time }\end{array}$ & $\begin{array}{l}\text { Some of the } \\
\text { time }\end{array}$ & $\begin{array}{l}\text { None of the } \\
\text { time }\end{array}$ & $\mathrm{N} / \mathrm{A}$ \\
\hline 6 & Reading? & & & & & & $\mathrm{N} / \mathrm{A}$ \\
\hline 7 & Driving at night? & & & & & & $\mathrm{N} / \mathrm{A}$ \\
\hline 8 & Working with a computer or bank machine (ATM)? & & & & & & $\mathrm{N} / \mathrm{A}$ \\
\hline \multirow[t]{2}{*}{9} & Watching TV? & & & & & & $\mathrm{N} / \mathrm{A}$ \\
\hline & & (4) & (3) & (2) & (1) & (0) & \\
\hline \multicolumn{8}{|c|}{$\begin{array}{l}\text { N/A: Should be marked when there is no observation } \\
\text { Subtotal score for answers } 6 \text { to 9: (B) }\end{array}$} \\
\hline \multicolumn{8}{|c|}{ Have your eyes feel uncomfortable in any of the following situations during the last week? } \\
\hline & & $\begin{array}{l}\text { All of the } \\
\text { time }\end{array}$ & $\begin{array}{l}\text { Most of the } \\
\text { time }\end{array}$ & $\begin{array}{l}\text { Half of the } \\
\text { time }\end{array}$ & $\begin{array}{l}\text { Some of the } \\
\text { time }\end{array}$ & $\begin{array}{l}\text { None of the } \\
\text { time }\end{array}$ & $\mathrm{N} / \mathrm{A}$ \\
\hline 10 & Windy conditions? & & & & & & $\mathrm{N} / \mathrm{A}$ \\
\hline 11 & Places or areaswith low humidity (very dry)? & & & & & & $\mathrm{N} / \mathrm{A}$ \\
\hline \multirow[t]{2}{*}{12} & Areas that are air conditioned? & & & & & & $\mathrm{N} / \mathrm{A}$ \\
\hline & & (4) & (3) & (2) & $(1)$ & (0) & \\
\hline \multicolumn{8}{|c|}{$\begin{array}{l}\text { N/A: Should be marked when there is no observation } \\
\text { Subtotal score for answers } 10 \text { to } 12:(C)\end{array}$} \\
\hline \multicolumn{8}{|c|}{$\begin{array}{c}\text { Add subtotals } A, B \text {, and } C \text { to obtain } D \\
\text { (A+B+C=D) } \\
\text { (D= Sum of scores for all questions answered) } \\
\text { Total number of questions answered }=E \\
\text { (Do not include questions answered N/A) } \\
\text { OSDI = (D X 25) / E }\end{array}$} \\
\hline
\end{tabular}


Finally, all participants underwent Schirmer I test, Schirmer II test, TBUT, and ocular surface staining, normal values of which are $\geq 10 \mathrm{~mm}, \geq 5 \mathrm{~mm}$, $\geq 10$ seconds, and no staining (absent), respectively. As is known, there are two types of the Schirmer test commonly used in clinical practice: Schirmer I (reflex and basal tears) and Schirmer II (basal secretion). The Schirmer test was firstly performed without topical anesthesia (Schirmer I test) and 30 minutes later it was re-administered to the same individual after topical anesthesia (0.5\% proparacaine $\mathrm{HCl}$, Alcaine; Alcon, TX, USA) in both eyes simultaneously (Schirmer II test). The standard Schirmer filter paper test strip, $35 \mathrm{~mm}$ long and $5 \mathrm{~mm}$ width, was gently placed in the inferior temporal conjunctival cul-de-sac of both eyes. The filter paper test strip was removed after 5 minutes and the length of the tear wetting was measured in millimeters. A reading of 10 $\mathrm{mm}$ or greater and $5 \mathrm{~mm}$ or greater was considered the cut-off for a normal value for Schirmer I test and Schirmer II test, respectively. The fluorescein strip was moistened with saline and then gently placed in the inferior cul-de-sac of each eye. The TBUT was evaluated by observing and viewing the fluoresceindyed tear film under a wide cobalt blue illumination of the slit-lamp biomicroscopy and by measuring the time in seconds at which the first dry spot on the corneal surface appeared after blinking (Figure 1). Ten seconds or greater was considered the cut-off for a normal value for TBUT. The Oxford grading scheme is used to quantify the amount of ocular epithelial surface damage in patients with DED. According to the Oxford grading scheme, ocular surface staining is evaluated in a range from 0 (absent) to 5 (severe ${ }^{20}$ (Figure 2). After the TBUT, the corneal region, nasal and temporal conjunctival staining in the interpalpebral space were examined with a slit-lamp microscopy under cobalt light and graded according to the Oxford grading scheme (Figure 3,4). After the ocular surface fluorescein staining, lissamine green strips were moistened with saline and gently placed in the inferior cul-de-sac of each eye for evaluating the ocular surface staining. Then, the corneal region, nasal and temporal conjunctival lissamine green staining in the interpalpebral space were examined with a slit-lamp biomicroscopy under medium intensity white light and graded according to the Oxford grading scheme (Figure 3, 4). The mean TBUT values, Schirmer I-II test values, and ocular surface staining scores of the right and left eyes were used for statistical analysis.

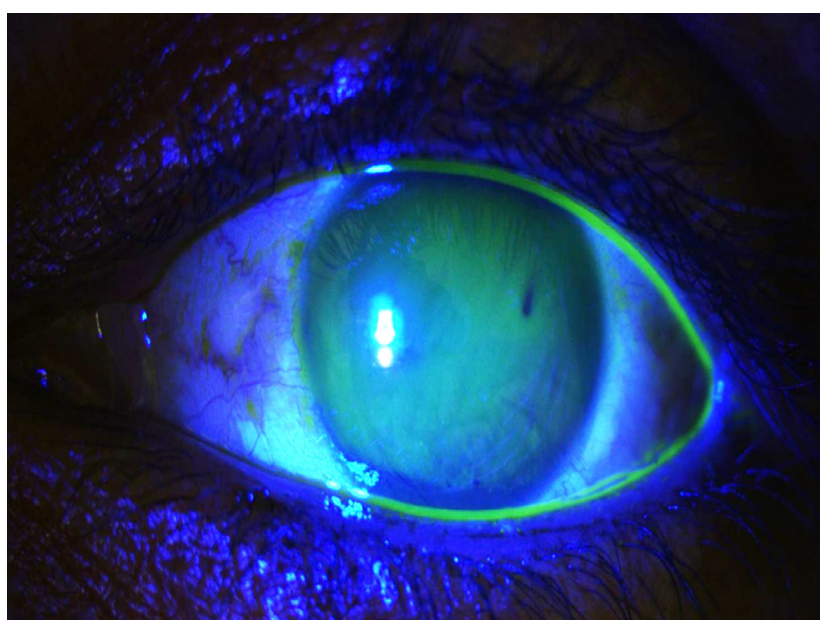

Figure 1. Tear break-up time showing breaks in the fluorescein-dyed tear film under a wide cobalt blue illumination of the slit-lamp biomicroscopy.

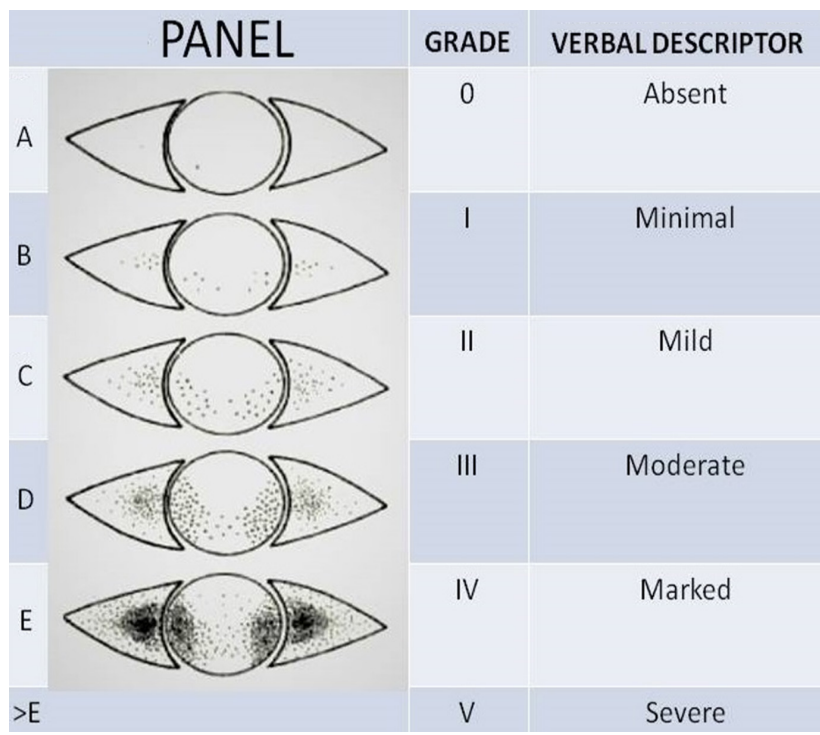

Figure 2. A representative grading A-E panels and indicating the numerical grade between 0-5 for each panel and the verbal descriptor for each grade (Oxford Grading Scheme).

\section{Statistical analysis}

All data were analyzed using statistical software SPSS for Windows version 18.0 software (SPSS Inc, Chicago, IL, USA). The mean values of the OSDI score and dry eye test parameters were determined. The relationship between categorical data was determined by the Chi-square test. The continuous variables in two groups were compared by the Mann-Whitney U test. The continuous variables in three and more groups were compared by the Kruskal-Wallis test. The correlation between continuous variables was compared by the Spearman test. The P-value of less than 0.05 was considered statistically significant. 

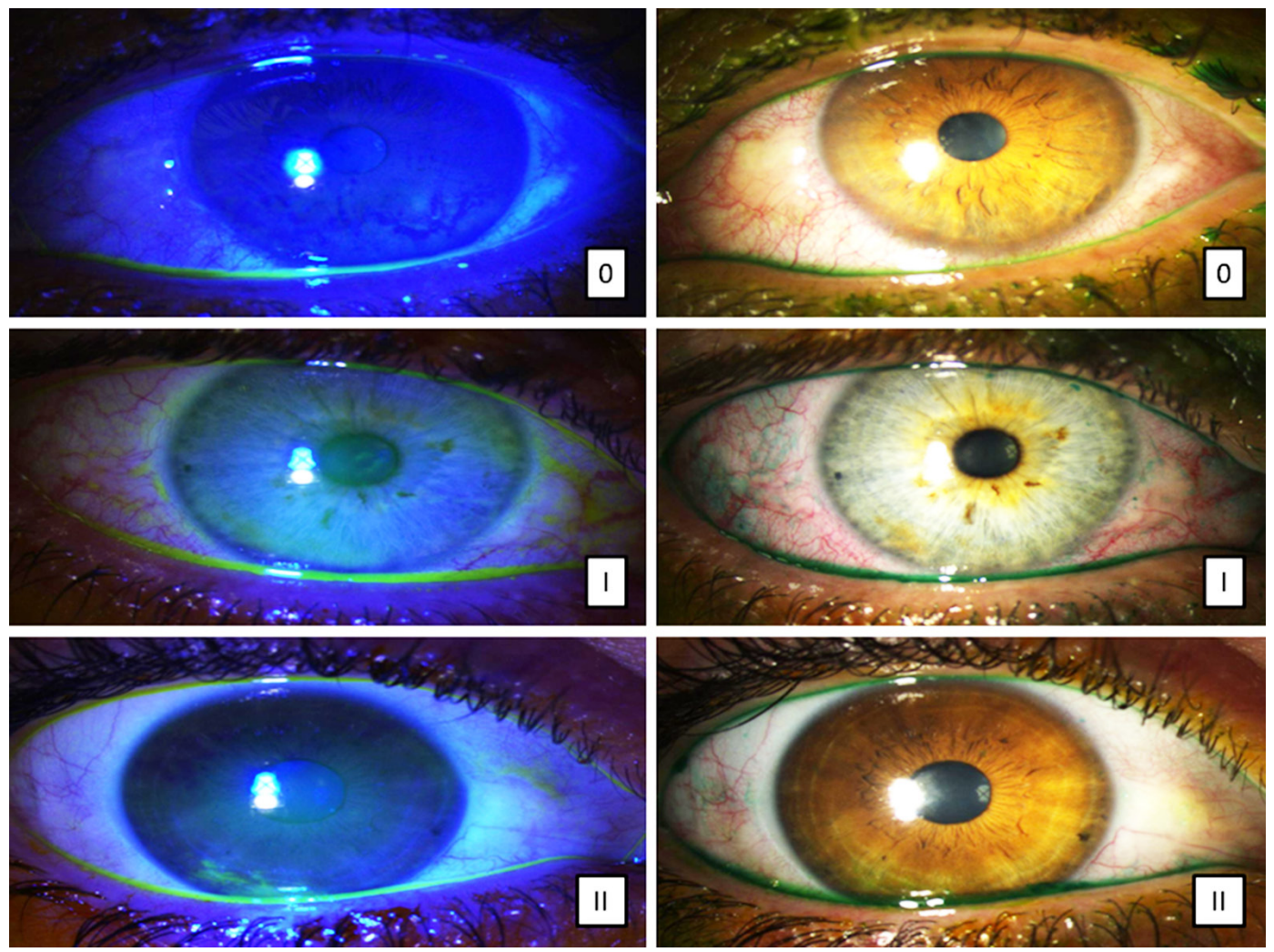

Figure 3. A representative of staining of the corneal and conjunctival surface epithelium with fluorescein and lissamine green and indicating the numerical grade (O, I, II) and the verbal descriptor (Absent, Minimal, and Mild) of the Oxford grading scheme.
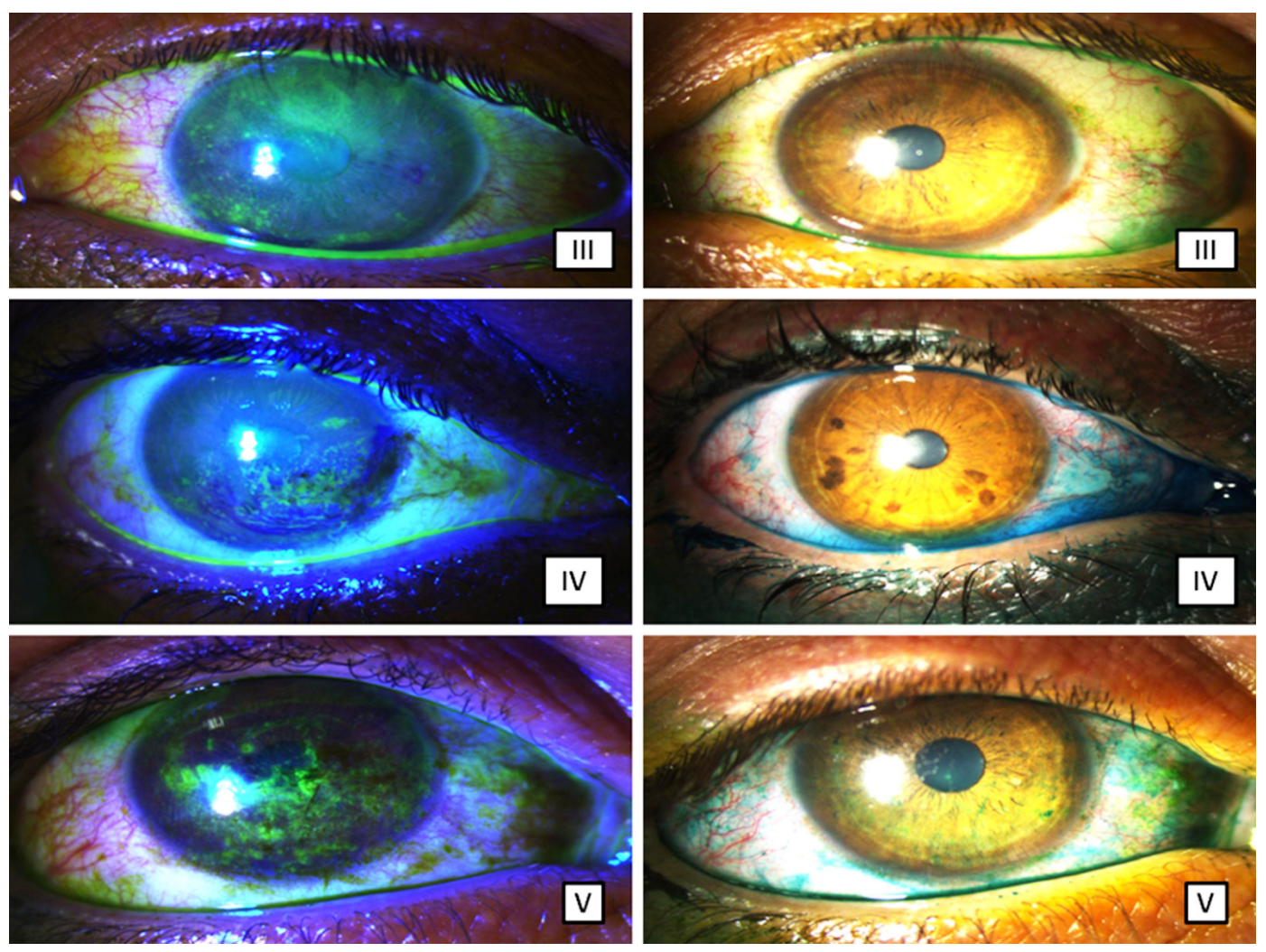

Figure 4. A representative of staining of the corneal and conjunctival surface epithelium with fluorescein and lissamine green and indicating the numerical grade (III, IV, V) and the verbal descriptor (Moderate, Marked, and Severe) of the Oxford grading scheme. 


\section{Results}

Of 62 participants, $42 / 62(67.7 \%)$ were female and $20 / 62(32.3 \%)$ were male. The mean age of participants was $30.06 \pm 4.794(21-39)$ years. The mean computer use time of the participants was $10.15 \pm$ 3.040 (6-16) hours/day. The mean wearing glasses and smoking were $17 / 62$ (27.4\%) and 46/62 (74.2\%), respectively. Demographic data are presented in Table 2. The mean OSDI score was $31.0742 \pm 15.05892$ (8.375). According to the OSDI grading scale, $5(8.1 \%)$ participants had normal, 15 (24.2\%) mild, 23 (37.1\%) moderate, and 19 (30.6\%) had severe ocular surface disease. The mean values of Schirmer I test, Schirmer II test, and TBUT were $25.10 \pm 6.518 \mathrm{~mm}, 12.21$ $\pm 6.268 \mathrm{~mm}$ and $8.71 \pm 4.575$ seconds in the right eye, respectively. The mean values of Schirmer I test, Schirmer II test, and TBUT were $24.98 \pm 6.253 \mathrm{~mm}$, $12.29 \pm 5.646 \mathrm{~mm}$ and $8.94 \pm 4.081$ seconds in the left eye, respectively. According to grading of corneal and conjunctival staining in the right eye (Oxford grading scheme) $6(9.7 \%)$ participants had no ocular surface disease (absent), 12 (19.4\%) minimal, 17 (27.4\%) mild, $14(22.6 \%)$ moderate, 10 (16.1\%) marked and $3(4.8 \%)$ had severe corneal and conjunctival staining and in the left eye $6(9.7 \%)$ participants had no ocular surface disease (absent), 11 (17.7\%) minimal, 20 (32.3\%) mild, 13 (20.9\%) moderate, 7 (11.3\%) marked and $5(8.1 \%)$ had severe corneal and conjunctival staining. Clinical data are presented in Table 3. There was a significant negative correlation between OSDI score and TBUT in the right eye $(\mathrm{r}=-0.718, \mathrm{p}=0.000)$ and the left eye $(r=-0.667, p=0.000)$. However, there was a slightly negative correlation between OSDI score and Schirmer I-II tests in the right eye $(r=-0.273, p$ $=0.032 ; \mathrm{r}=-0.295, \mathrm{p}=0.020)$ and the left eye $(\mathrm{r}=$ $-0.308, p=0.015 ; \mathrm{r}=-0.296, \mathrm{p}=0.019)$, respectively. There was also a significant negative correlation between computer use time and TBUT in the right eye $(\mathrm{r}=-0.960, \mathrm{p}=0.000$ for right $)$ and the lefte ye $(\mathrm{r}=$ $-0.831, \mathrm{p}=0.000)$. However, there was no significant correlation between TBUT and Schirmer I-II tests in the right eye $(p=0.394, p=0.233)$ and the left eye $(p=0.579, p=0.491)$, respectively. There was a significant difference between OSDI score and ocular surface staining scores in both eyes $(p=0.000)$. There was a significant positive correlation between OSDI score and computer use time $(\mathrm{r}=0.642, \mathrm{p}=0.000)$. There was also a significant positive correlation between the ocular surface staining scores and computer use time in both eyes $(p=0.000)$. However, there was
Table 2. The demographic features of the individuals

\begin{tabular}{|c|c|c|c|c|}
\hline & \multicolumn{4}{|c|}{ Values } \\
\hline & Min.-Max. & Mean \pm SD & $\mathrm{n}(\%)$ & Present/Total (\%) \\
\hline Age (years) & $21-39$ & $30.06 \pm 4.794$ & & \\
\hline \multicolumn{5}{|l|}{ Gender } \\
\hline Male & & & $42(67.7)$ & \\
\hline Female & & & $20(32.3)$ & \\
\hline $\begin{array}{l}\text { Computer use } \\
\text { (hours/day) }\end{array}$ & $6-16$ & $10.15 \pm 3.040$ & & \\
\hline $\begin{array}{l}\text { Wearing } \\
\text { glasses }\end{array}$ & & & & $17 / 62(27.4)$ \\
\hline Smoking & & & & $46 / 62(74.2)$ \\
\hline
\end{tabular}

Table 3. The results of the ocular surface disease index and dry eye test parameters of the individuals ( $n=62$ Individuals, 124 Eyes)

\begin{tabular}{|c|c|c|c|}
\hline & \multicolumn{3}{|c|}{ Values } \\
\hline & Min.-Max. & Mean \pm SD & $\mathrm{n}(\%)$ \\
\hline OSDI score & $8.3-75$ & $31.1 \pm 15.1$ & \\
\hline \multicolumn{4}{|c|}{ OSDI grading scores } \\
\hline Normal & & & $5(8.1)$ \\
\hline Mild & & & $15(24.2)$ \\
\hline Moderate & & & $23(37.1)$ \\
\hline Severe & & & $19(30.6)$ \\
\hline Total & & & $62(100)$ \\
\hline \multicolumn{4}{|l|}{ Schirmer I (mm) } \\
\hline Right eye & $8-35$ & $25.10 \pm 6.518$ & \\
\hline Left eye & $9-34$ & $24.98 \pm 6.253$ & \\
\hline \multicolumn{4}{|l|}{ Schirmer II (mm) } \\
\hline Right eye & $1-30$ & $12.21 \pm 6.268$ & \\
\hline Left eye & $2-26$ & $12.29 \pm 5.646$ & \\
\hline \multicolumn{4}{|l|}{ TBUT (second) } \\
\hline Right eye & $2-25$ & $8.71 \pm 4.575$ & \\
\hline Left eye & $4-23$ & $8.94 \pm 4.081$ & \\
\hline \multicolumn{4}{|c|}{ Ocular surface staining scores } \\
\hline \multicolumn{4}{|l|}{ Right eye } \\
\hline Absent & & & $6(9.7)$ \\
\hline Minimal & & & $12(19.4)$ \\
\hline Mild & & & $17(27.4)$ \\
\hline Moderate & & & $14(22.6)$ \\
\hline Marked & & & $10(16.1)$ \\
\hline Severe & & & $3(4.8)$ \\
\hline Total & & & $62(100)$ \\
\hline \multicolumn{4}{|l|}{ Left eye } \\
\hline Absent & & & $6(9.7)$ \\
\hline Minimal & & & $11(17.7)$ \\
\hline Mild & & & $20(32.3)$ \\
\hline Moderate & & & $13(20.9)$ \\
\hline Marked & & & $7(11.3)$ \\
\hline Severe & & & $5(8.1)$ \\
\hline Total & & & $62(100)$ \\
\hline
\end{tabular}


no correlation between age, gender, smoking and wearing glasses and OSDI score, Schirmer I test, Schirmer II test, TBUT, and ocular surface staining scores ( $\mathrm{p}>$ $0.05)$. Moreover, there was no statistically significant correlation between the duration of computer use and the Schirmer I-II tests in the right eye $(\mathrm{p}=0.460, \mathrm{p}$ $=0.269)$ and the left eye $(p=0.322, p=0.213)$, respectively.

\section{Discussion}

With the invent of the internet, the internet network has progressively spread around the world. Therefore, the use of computers and digital electronic devices for e-mail and internet access for vocational and avocational activities has gradually become widespread in developed and developing societies. Many individuals use multiple devices such as desktop and laptop computers as well as handheld electronic devices ${ }^{2}$. Considering the tremendous growth rates of digital device use in recent years, it is an inevitable reality that millions of people of all ages will be affected by the $\mathrm{DED}^{4}$. The DED is known to increase with age, but there is also a significant increase of DED in younger people due to the longer duration of occupational sitting and the higher daily computer use. It is a fact that DED is an important concern among office computer workers. Therefore, as the prevalence of DED is higher among office computer workers, this population is of great importance and should not be ignored. A number of factors and a wide spectrum of diseases including long-term computer use, longer duration of occupation, lower ergonomics practices knowledge, lack of visual display terminal (VDT) filter, systemic diseases, medications, contact lens wear, female gender, and preexisting ocular conditions may play a role in $\mathrm{DED}^{2,3,21}$. However, other causes of dry eye are not discussed in this paper.

The aim of this study was to detect the presence and prevalence of dry eye only in long-term computer users. In this study, the mean age of the participants was $30.06 \pm 4.794$. It was remarkable that this value was well below the age group in which dry eye syndrome was frequently experienced. The mean computer use time was $10.15 \pm 3,040$ hours/day. This current study is consistent with the literature, the overwhelming majority of the participants had longer duration of occupation, prolonged computer use, lower ergonomics practices knowledge, and lack of VDT filter. There are several tests and applications to detect DED, including symptom questionnaires, Schirmer I test, Schirmer II test, TBUT, ocular surface epithelial staining scores, tear function index, tear osmolarity, impression cytology, fluorophotometry, tear fluid protein immunoassays, tear ferning test, and other tests (meibometry, meibography, or meiboscopy) $)^{22}$.

In this cross-sectional study, we performed tests and applications such as OSDI score, Schirmer I test, Schirmer II test, TBUT, and corneal and conjunctival epithelial staining pattern test. The OSDI is a questionnaire that assesses the severity of DED and its effect on the ocular surface and visual symptoms. The aim of this questionnaire is to make the diagnosis of DED more reliable by considering the patients' symptoms. The OSDI questionnaire is a simple and inexpensive assessment method that can be used outside the clinic in daily practice without requiring any device or equipment ${ }^{18,19}$. Gümüş et $\mathrm{al}^{23}$. reported that the mean OSDI score of individuals with an average computer use time of $8.3 \pm 1.1$ hours was $46.7 \pm 14.9$. In one study, the mean OSDI score was found to be $43.41 \pm 12.6$ in participants with a computer use time of more than 6 hours per day ${ }^{17}$. In another study conducted by Simavli et $\mathrm{al}^{24}$. the mean OSDI score was $44.1 \pm 24.7$, the OSDI score of individuals using computers for eight hours or more per day were significantly higher than those using computers for less than eight hours. There was a significant positive correlation between OSDI score and daily computer use, ocular surface staining scores and female gender. No correlation was found between age, smoking, type of computer, wearing glasses, basal secretion test, and OSDI score. However, Xu et $\mathrm{al}^{25}$. indicated that smoking may be associated with the risk of dry eye in the general population. In parallel, in this current study, the mean OSDI score was found to be $31.077 \pm 15.05892$ in individuals who use computers for at least six hours a day and have an average computer use time of $10.15 \pm 3.040$ hours/day. The OSDI score of the individuals using more than six hours of computer a day was significantly higher than those using the computer for 6 hours. Similarly, an increase in ocular surface staining scores and a decrease in TBUT were observed in office workers who were in front of computers for more than 6 hours. However, there was no statistically significant correlation between the duration of computer use and Schirmer I-II tests. Additionally, there was no correlation between age, gender, smoking and wearing glasses and OSDI score, Schirmer I test, Schirmer II test, TBUT, and ocular surface staining scores. Schirmer's test is not a 
good and reliable test for the diagnosis of the DED, because reflex epiphora can cause normal evaluation of dry eye patients ${ }^{26}$. Gümüş et $\mathrm{al}^{23}$. conducted a study on computer workers in the office, the TBUT was shorter in the evening hours and higher ocular surface staining scores were found. However, there was no significant change in Schirmer's test. Singh and Singh ${ }^{27}$ also reported that Schirmer I test results changed with reflex epiphora, there was no correlation with symptoms in DED, so Schirmer I test is not a reliable test for the evaluation of the DED. In another study of 68 patients, a significant negative correlation was found between the OSDI score and TBUT, yet no significant correlation was found with the Schirmer's test ${ }^{28}$. Similarly, in another study with 35 patients, the correlation between OSDI score, TBUT and Schirmer's test was investigated and similar results were found ${ }^{26}$. In this cross-sectional study, there was a significant positive correlation between OSDI score and daily computer use, ocular surface staining scores. Additionally, there was a negative correlation between OSDI score and TBUT, but there was a slightly negative correlation between OSDI and Schirmer I-II tests. However, there was no significant correlation between the TBUT and Schirmer I-II tests. The mean Schirmer I test was 25.10 $\pm 6.518 \mathrm{~mm}$ in the right eye and $24.98 \pm 6.253 \mathrm{~mm}$ in the left eye. Schirmer I test was below $10 \mathrm{~mm}$ only in two individuals (3.22\%). In accordance with the literature, the mean values of the Schirmer I test were also very high in this study. The mean Schirmer II test was $12.21 \pm 6.268 \mathrm{~mm}$ in the right eye and $12.29 \pm 5.646$ $\mathrm{mm}$ in the left eye. Schirmer II test was below $5 \mathrm{~mm}$ only in four individuals (6.45\%). However, the mean TBUT was $8.71 \pm 4.575$ seconds in the right eye and $8.94 \pm 4.081$ seconds in the left eye. The TBUT was below 10 seconds in forty-four individuals (70.96\%). Moreover, the ocular surface staining scores were only normal (absent or no staining) in six individuals (9.67\%). The OSDI score showed similar characteristics as in the TBUT and ocular surface staining scores. According to the OSDI score, only five individuals were normal (8.1\%). Therefore, the validity, reliability, accuracy, sensitivity, and specificity of the measurements of the Schirmer I test and Schirmer II test should be questioned. As a result, these findings suggest that the combined use of OSDI score, TBUT, and ocular surface staining scores in daily clinical ophthalmic practices greatly supports the diagnosis of DED. In light of this study, the Schirmer's test is not consistent with the OSDI score and other dry eye test parameters in clinical ophthalmic practice and hence is not a reliable test.

Normal blinking is very crucial for tear film stability and the protection of the ocular surface ${ }^{29}$. The number of blinking is normally between $10-15 /$ minute and this rate decreases considerably during computer use $^{30}$. Long-term computer use has been associated with both a reduced blink rate and a high number of incomplete blinking as compared to relaxed individu$\mathrm{als}^{2}$. Portello et $\mathrm{al}^{29}$. reported that reduced blinking during computer use caused the tear film to evaporate, causing symptoms of dry eye. In another similar study, Büyükbaş et $\mathrm{a}^{17}$. reported a decrease in the number of blinking and deterioration in tear function tests with long-term computer use. Blehm et $\mathrm{al}^{21}$. noted that reduced blink rate or incomplete blinking, environmental factors, excessive corneal exposure, old aged and women gender, systemic diseases and medications, contact lens wear and ocular conditions lead to corneal drying. Unfortunately, the measurement of the blink rate was not evaluated in this present study.

It was demonstrated that computer users constantly report dry eye, burning, and grittiness after a long-term duration of work $^{21}$. Dry eye may play an important role in the etiology of $\mathrm{CVS}^{2}$. The CVS is a group of eye and vision problems related to excessive computer use. With excessive use of computers, CVS has become very common in the world, and around 60 million people worldwide suffer from CVS and one million new people are added each year ${ }^{1-3}$. It is not only resulting in visual discomfort but also resulting in low quality of life and low productivity in the workplace ${ }^{1-3,15,16}$. In addition to the negative impacts of the CVS on visual comfort, quality of life, and work productivity, it is clear that its economic impact is extremely high and that minimizing symptoms that reduce productivity at work will provide significant financial benefits ${ }^{1-3}$. The DED also affects the quality of life of individuals, including social, physical, psychological and workplace productivity ${ }^{7,12}$. Patel et $\mathrm{a}^{12}$. found that DED negatively impacts on daily activities, workplace performance, and work productivity.

Dry eye symptoms may be exacerbated due to low environmental humidity and forced-air conditioning ${ }^{2}$. In this study, the majority of computer users were working in closed, low environmental humidity and poorly ventilated environments. However, there was no statistically significant correlation between OSDI score, dry eye test parameters, and smoking. As a result, despite 
the fact that the Schirmer's test is cheap, quick, and universally available, it is not a preferable test in clinical ophthalmic practice, because of the lack of consistency in its use in detecting DED. As is known, in addition to OSDI score and TBUT in the detection of DED, corneal and conjunctival staining is a useful method to evaluate the integrity of ocular surfaces. The combination of OSDI score, TBUT, and ocular surface staining scores seems to be sufficient in identifying a large number of patients with DED. Although evaluation of objective corneal and conjunctival staining is important for recording pathology, monitoring therapeutic response, and comparing research intervention, it has not been developed for practical use in ophthalmic settings. It is a fact that manual examination of dry eye tests is time-consuming, costly, prone to human errors and bias, due to current population growth trends and the lack of resources and limited availability of ophthalmologists. In near future, I anticipate that these problems will be overcome with artificial intelligence without the need for human resources and without the possibility of human errors and that the tests will be performed faster, more practical, and more reliable in ophthalmic settings.

\section{The Future of Artificial Intelligence in Dry Eye Disease}

Artificial intelligence has been used to confirm the diagnosis and treatment of diseases in ophthalmic settings, to read images, to perform corneal topographic mapping and to calculate intraocular lens. In recent, comprehensive clinical researches are being conducted on automated applications for the diagnosis and treatment of diabetic retinopathy, diabetic macular edema, age-related macular degeneration, glaucoma, and other ophthalmic diseases. Of note, it is inevitable that the clinical applications of artificial intelligence become a routine diagnostic and treatment modality in both ophthalmic healthcare services and other healthcare disciplines. The present study demonstrated that the evaluation of the OSDI questionnaire and TBUT and ocular surface staining scores together, they are sufficient and reliable application for the diagnosis of DED. However, considering the current population growth trends and the lack of resources, and the limited availability of ophthalmologists, manual examination is time-consuming, costly, prone to human errors, and bias. Therefore, considering the lack of resources and patient density; easier, more practical, more reliable, and faster tests are needed in ophthalmic healthcare services. Therefore, in the near future, the detection of DED and other ophthalmic diseases through unmanned automated applications system in ophthalmic healthcare services will become a necessity ${ }^{31}$.

\section{Conclusion}

In modern society, the use of electronic devices has become widespread in individuals of all ages for both business and leisure activities. Nowadays, computers are one of the most common office tools used in all institutions and organizations for a wide range of professional or non-professional purposes. Long-term computer use and longer duration of occupation not only cause serious ocular surface complications but also reduce workplace performance, work productivity and as well as reduce the quality of life of the office workers.

In conclusion, in this current study conducted in ophthalmology clinic of our university, the DED is experienced more frequently in office workers in accordance with the literature. The DED, very common in our country as well as in the world, reduces the quality of life, workplace performance, work productivity and therefore has a significant impact on the economy. As a result, these research findings tend to point out that long-term computer use, longer duration of occupation, and lower ergonomics practices knowledge are associated with the severity of the DED. The DED is a treatable eye condition and it is an eye condition that should not be neglected, causing serious ocular surface complications if left untreated. Therefore, if adequate medical and institutional measures are not taken in the future, it is likely that the DED and therefore the CVS will continue to make an increasing negative contribution to ocular health, quality of life and economic losses. It is concluded that further recommendations and information are needed to reduce the risk of developing DED among young computer users.

Of note, in light of this study, these findings suggest that using the OSDI score, TBUT, and ocular surface staining scores together is an important step in identifying a large number of DED. However, associations between OSDI score, TBUT, ocular surface staining scores, dry eye symptoms, and Schirmer's test were low and inconsistent. It also shows that the combined use of OSDI score, TBUT, and ocular surface staining scores is practical, reliable and useful for the diagnosis of the DED. However, in the intensive clinical ophthalmic healthcare services, the manual examination of dry eye tests is time-consuming, costly, prone to human errors and bias, due to current population growth 
trends and the lack of resources and limited availability of ophthalmologists. Therefore, it is obvious that it will provide incredible convenience in the future to detect the DED through unmanned automated applications in ophthalmic healthcare services. Of note, this study demonstrates that long-term computer use and longer duration of occupation result in significant alteration of ocular surface parameters producing ocular surface morbidity. However, further longitudinal prospective studies are needed to establish causality for identified risk factors for DED.

\section{Acknowledgments}

The abstract of this paper has been published in 53th National Congress of Turkish Ophthalmological Association, November 6-10, 2019 Kemer-Antalya, Turkey.

\section{Financial Disclosure}

The author received no specific funding for this work.

\section{Conflicts of Interests}

The author reports no conflicts of interest in this work.

\section{References}

1. Sen A, Richardson S. A study of computer-related upper limb discomfort and computer vision syndrome. J Hum Ergol (Tokyo)2007;36(2):45-50.

2. Rosenfield M. Computer vision syndrome: a review of ocular causes and potential treatments. Ophthalmic Physiol Opt 2011;31:502-15.

3. Ranasinghe P, Wathurapatha WS, Perera YS, Lamabadusuriya DA, Kulatunga S, Jayawardana $\mathrm{N}$ et al. Computer vision syndrome among computer office workers in a developing country: an evaluation of prevalence and risk factors. BMC Res Notes 2016;9:150.

4. Sheppard AL, Wolffsohn JS. Digital eye strain: prevalence, measurement and amelioration. BMJ Open Ophthalmol 2018;3(1): e000146.

5. Perry HD. Dry eye disease: pathophysiology, classification, and diagnosis. Am J Manag Care 2008;14(3 Suppl): S79-87.

6. The definition and classification of dry eye disease: report of the definition and classification subcommittee of the international dry eye workshop(2007). Ocul Surf 2007;5(2):75-92.

7. Uchino M, Schaumberg DA. Dry eye disease: impact on quality of life and vision. Curr Ophthalmol Rep 2013;1:51-7.
8. Zhang X, M VJ, Qu Y, He X, Ou S, Bu J et al. Dry eye management: targeting the ocular surface microenvironment. Int J Mol Sci 2017;18(7). pii: E1398.

9. Çelik T. Kuru göz semptomları olan bilgisayar kullanıcılarında gözyaşı film tabakasının oküler yüzey hastalığı indeksi, gözyaşı kırılma zamanı ve Schirmer testi ile değerlendirilmesi. MN Oftalmoloji 2017;24:5-8.

10. Kuo YK, Lin IC, Chien LN, Lin TY, How YT, Chen KH et al. Dry eye disease: a review of epidemiology in Taiwan, and its clinical treatment and merits. J Clin Med 2019;8(8). pii: E1227.

11. Koban Y, Deniz R, Baykuş Y, Balyen L, Çelik H. Evaluation of changes in meibomian glands in polycystic ovary syndrome by noncontact infrared meibography. J Surg Med 2019;3(9):7114.

12. Patel VD, Watanabe JH, Strauss JA, Dubey AT. Work productivity loss in patients with dry eye disease: an online survey. Curr Med Res Opin 2011;27(5):1041-8.

13. Rolando M, Cantera E, Mencucci R, Rubino P, Aragona P. The correct diagnosis and therapeutic management of tear dysfunction: recommendations of the P. I. C. A. S. S. O. board. Int Ophthalmol 2018;38(2):875-95.

14. Smith W, McMahon D, Nymark M. A novel combination therapy for patients with dry eye disease: a pilot study. Altern Ther Health Med 2018;24(3):12-5.

15. Thomson WD. Eye problems and visual display terminalsthe facts and the fallacies. Ophthalmic Physiol Opt 1998;18(2):111-9.

16. Hayes JR, Sheedy JE, Stelmack JA, Heaney CA. Computer use, symptoms, and quality of life. Optom Vis Sci 2007;84(8):73844 .

17. Büyükbaş Z, Gündüz MK, Bozkurt B, Zengin N. Bilgisayar kullanıcılarında görülen oküler yüzey değişikliklerinin değerlendirilmesi. Turk J Ophthalmol 2012;42;190-6.

18. Schiffman RM, Christianson MD, Jacobsen G, Hirsch JD, Reis BL. Reliability and validity of the ocular surface disease index. Arch Ophthalmol 2000;118(5):615-21.

19. Miller KL, Walt JG, Mink DR, Satram-Hoang S, Wilson SE, Perry HD et al. Minimal clinically important difference for the ocular surface disease index. Arch Ophthalmol 2010;128(1):94-101.

20. Bron AJ, Evans AND, Smith JA. Grading of corneal and conjunctival staining in the context of other dry eye tests. Cornea 2003;22:640-50.

21. Blehm C, Vishnu S, Khattak A, Mitra S, Yee RW. Computer vision syndrome: a review. Surv Ophthalmol 2005;50(3):25362.

22. Phadatare SP, Momin M, Nighojkar P, Askarkar S, Singh KK. A comprehensive review on dry eye disease: diagnosis, medical management, recent developments and future challenges. Adv. Pharm 2015;2015:12.

23. Gümüş K, Arda H, Öner AÖ, Karaküçük S, Mirza E. Bilgisayar kullanımının kuru göz parametreleri üzerine olan etkisinin değerlendirilmesi. T Oftalmoloji Derg 2009;39:244-9. 
24. Simavlı H, Önder Hİ, Bucak YY, Erduruş M, Güler E, Hepşen İF. Bilgisayar kullanıcılarında görülen oküler yüzey hastalık indeksi ile kuru göz testleri ve demografik özellikler arasındaki ilişki. T Oftalmoloji Derg 2014;44:115-8.

25. Xu L, Zhang W, Zhu XY, Suo T, Fan XQ, Fu Y. Smoking and the risk of dry eye: a meta-analysis. Int J Ophthalmol 2016;9(10):1480-6.

26. Ünlü C, Güney E, Akçay BS, Akçalı G, Erdoğan G, Bayramlar $\mathrm{H}$. Comparison of ocular-surface disease index questionnaire, tearfilm break-up time, and Schirmer tests for the evaluation of the tearfilm in computer users with and without dry-eye symptomatology. Clin Ophthalmol 2012;6:1303-6.

27. Singh Bhinder G, Singh Bhinder H. Reflex epiphora in patients with dry eye symptoms: role of variable time Schirmer-1 test. Eur J Ophthalmol 2005;15(4):429-33.
28. Ozcura F, Aydin S, Helvaci MR. Ocular surface disease index for the diagnosis of dry eye syndrome. Ocul Immunol Inflamm 2007; 15:389-93.

29. Portello JK, Rosenfield M, Chu CA. Blink rate, incomplete blinks and computer vision syndrome. Optom Vis Sci 2013;90:482-7.

30. Hirota M, Uozato H, Kawamorita T, Shibata Y, Yamamoto S. Effect of incomplete blinking on tear film stability. Optom Vis Sci 2013;90:650-7.

31. Balyen L, Peto T. Promising artificial intelligence-machine learning-deep learning algorithms in ophthalmology. Asia Pac J Ophthalmol (Phila)2019;8(3):264-72. 